\title{
Oil and Gas Potential of Eurasian Western Arctic Shelf/Exploration in the Nearshore Area of Northeastern Baltic Shield
}

\author{
Sanghee Shin ${ }^{{ }^{*}}$, George V. Chilingar ${ }^{2}$, Oleg Sorokhtin ${ }^{3}$, Nikolai O. Sorokhtin ${ }^{4}$ \\ ${ }^{1}$ Geotechnical Engineering Research Division, Korea Institute of Construction Technology, \\ Goyang City, South Korea \\ ${ }^{2}$ Rudolf W. Gunnerman Energy and Environment Laboratory, University of Southern California, Los Angeles, USA \\ ${ }^{3}$ Geodynamics and paleo-oceanology Laboratory, Oceanology Institute, Russian Academy of Sciences, Moscow, Russia \\ ${ }^{4}$ Seismology and Geodynamics Laboratory, Oceanology Institute, Russian Academy of Sciences, Moscow, Russia \\ Email: ${ }^{*}$ scott@kict.re.kr
}

Received March 22, 2013; revised April 20, 2013; accepted May 20, 2013

Copyright (C) 2013 Sanghee Shin et al. This is an open access article distributed under the Creative Commons Attribution License, which permits unrestricted use, distribution, and reproduction in any medium, provided the original work is properly cited.

\begin{abstract}
A number of large and unique oil and gas fields were discovered over the western Arctic shelf of Eurasia. Some of them were partially appraised. Also, there are three potentially hydrocarbon-rich but insufficiently studied areas in the region. The discovery of commercial accumulations there would substantially increase the petroleum potential of the entire region. These areas are northern Murmansk Oblast, on the Rybachy Peninsula, the Franz-Joseph Land area, and the North Kara Shelf. It is suggested that oil and gas field discoveries in the former two areas are most expedient under current conditions. The oil and gas potential of the northwestern Kola Peninsula is reviewed in more detail.
\end{abstract}

Keywords: Arctic Shelf; Geodynamic Evolution; Baltic Shield; Oil Potential; Gas Potential

\section{Introduction}

Deciphering the nature of the region's geodynamic evolution and tying-up the lithospheric endogenous and exogenous activity with the formation of commercial-size concentrations of organic matter and, by the same token, of any commercial deposits is very important.

This is especially applicable to the Kola Peninsula (northeastern portion of the Baltic Shield). Oil and gas potential of its Riphaean sediments was being discussed since the 1970's. Lyubtsov et al. (1979) and Simonov (1998) described anomalously high hydrocarbon gas concentrations in the Riphaean of Rybachy and Sredny peninsulas and on the Kildin Island in the Barents Sea off the Kola Peninsula [1,2].

The Barents Sea is the northern extension of the Timan-Pechora Basin, whereas the Kara Sea is the northern extension of the West Siberian Basin, The World's largest sedimentary basin (Figure 1).

The writers studied for many years the issues of the Riphaean oil and gas potential on the Kola Peninsula and offshore Barents Sea. They came to a conclusion that the

${ }^{*}$ Corresponding author.

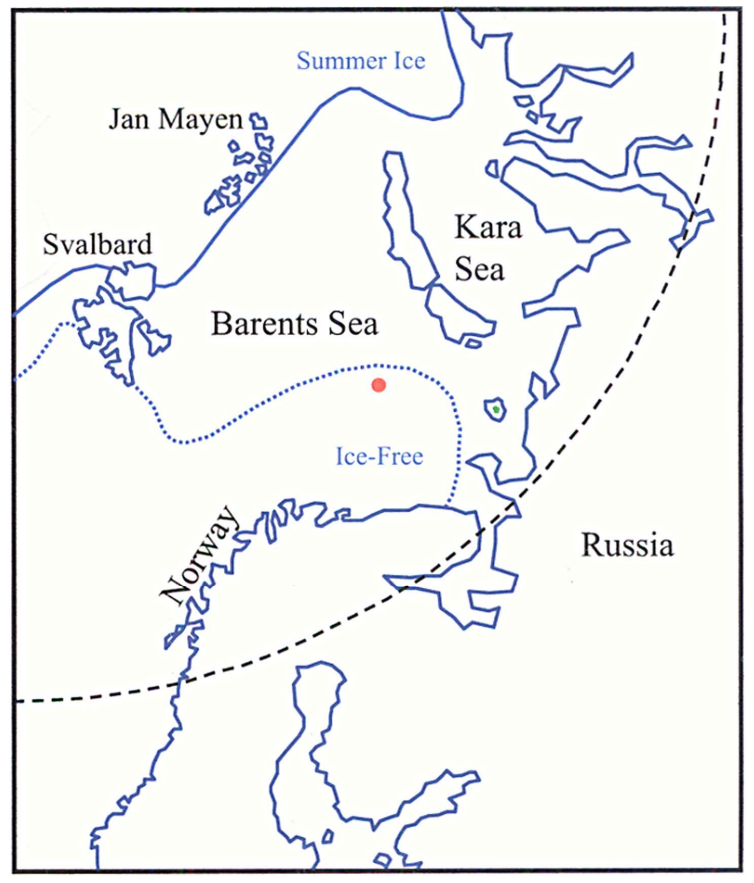

Figure 1. Locaiton of Barents Sea and Kara Sea. (Courtesy of Greg Croft Lnc). 
earliest hydrocarbon generation on the western Arctic shelf of Eurasia occurred due to the organic matter accumulation in the deposits over the passive continental margin in Middle and Late Proterozoic (1350-620 MMY). The area encompassed the northeastern fringe of the Baltic Shield and of the MezenSyneclise of the Russian Plate (Figure 2). Presently, the area is located northeast of the platform in the merger zone with the Barents Sea Plate and comprises the Timan-Varanger Belt's structurallithological complexes. 1) Baltic shield basement, Archaean; 2) Riphaean and Vendian sedimentary complexes; 3) basement of the Svalbard and North-Kara plates; 4) Urals and Novaya Zemlya folded formations (UralsMongolian belt); 5) Taymyr Peninsula folded formations; 6) sediment cover complexes of the East-European Platform; 7) sediment cover complexes of the Pechora Plate; 8) sediment cover complexes of the West Siberian and Siberian platforms; 9) folded formations of North-Atlantic belt's Caledonides; 10) potential oil- and gas-bearing structures including salt domes (based on geologic and geophysical information) and discovered hydrocarbon accumulations; 11) potential Riphaean oil and gas zone; 12) potential oil-bearing areas associated with Japetus Ocean closing in Early Ordovician-Late Devonian (505362 MMY); 13) potential oil- and gas- bearing areas associated with closing of the Paleo-Urals Ocean in Early Permian-Early Triassic (290-241 MMY); 14) biogenic and gas-hydrate (abiogenic) hydrocarbon formation zone over passive continental margin in Cenozoic (55-0 MMY); 15) limit of North-Atlantic Belt Caledonian folded formations on Barents Sea shelf; 16) edge suture of the continental margin type Timan-Varanger system; 17) migration of hydrocarbons generated in RiphaeanVendian; 18) migration of hydrocarbons generated in Early Ordovician-Late Devonian; and 19) migration of hydrocarbons generated in Early Permian-Early Triassic.

The Riphaeanpaleo-ocean has been closing in Late Riphaean. A boundary structure formed as a result, which

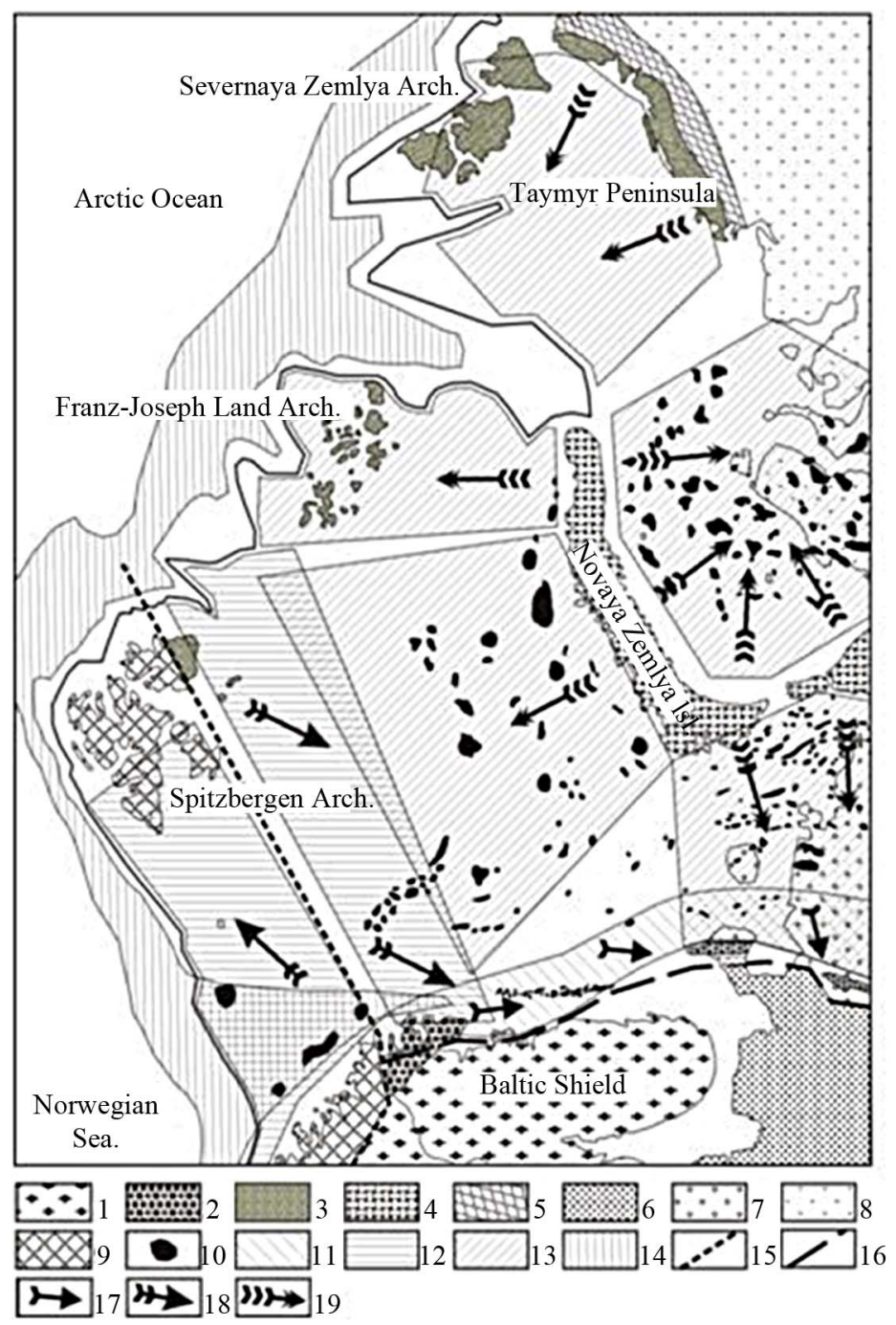

Figure 2. Schematic map of potential oil and gas occurrences on the Russia's Barents Sea-Kara plates. 
is totally lacking any traces of the contemporary collision magmatism, metamorphism and folding. However, it includes thick non-metamorphic and slightly metamorphic nearshore marine and marine Riphaean sequences similar in their composition with the shelf and slope sediments of a passive continental margin. Based on our analysis of geologic and geophysical data we suggest that the Timan-Vaganger zone is the preserved passive margin of an old lithospheric plate (Russian). After accretion to it of the Epi-Paleozoic Barents Sea Plate, the resulting entity became the East European Platform.

Most powerful increments of oil and gas potential in the region were associated with the Caledonian and Hercynian orogenies. They resulted in the formation of large and unique ${ }^{1}$ fields on the Svalbard, Pechora, North- and South-Kara plates and opened the buried oil and gas complexes of the previous (Riphaean-Vendian) period. It is known that the largest hydrocarbon accumulations form at the island arc or active continental margin obduction over the passive margins in the process of the ocean closing. The primary-migration accumulations emerge due to the mobilization of the organic matter dispersed in the sediments as well as due to the hydrocarbon supply from the subduction zone. The migration vector is usually perpendicular to the axis of the folding, and the distance can reach $500-600 \mathrm{~km}$ [3]. A similar scenario could have played out at the closing of the Japetus Ocean, which would have resulted in the oil and gas migration from the high pressure area (Caledonian folded system) to the tectonic discharge area (Figure 2).

The divergent migration illustrated in Figure 2 indicates the two-step ocean closing. First, the Greenland Plate was subducted under the Svalbard Plate, and then it began subducting under the Baltic Shield's Archaean and Proterozoic complexes. The Norway-Mezen rift system activation and intense evolution occurred at the same time. It could have resulted in the formation within its limits of large gas-hydrate aggregations. The wedgeshaped rift development (Varanger Graben) in the Caledonides' elbow bend and active hydrothermal activity and magmatism on its shoulders all indicate a possibility of gas-hydrate formation in the lower section. These gas-hydrates would have been similar to those discovered on the present-day continental slope of the Barents Sea Shelf [4].

This process was probably a cause of the elevated oil and gas potential of the Varanger and Rybachy peninsulas and Kildin Island fault/strike-slip fault structures. The vertical offsets reach $100-150 \mathrm{~m}$ (sometimes up to 1

\footnotetext{
${ }^{1}$ According to the official Russian classification, the fields are classified as unique if their oil/gas reserves exceed $300 \mathrm{MMT} / 500 \mathrm{BCM}$, and as large if their oil/gas reserves are 30 to $300 \mathrm{MMT} / 30$ to $500 \mathrm{BCM}$. The "reserves" are usually understood to actually be original oil-in-place and original gas-in-place and not the recoverable amounts.
}

$\mathrm{km}$ ), with the vertical component of about $60 \mathrm{~m}$. Salt diapirs may be potential traps. They are abundant in a close proximity of the Kola Peninsula shore and mark the rift's axis [5]. The validity of our suggestion was confirmed by recent discovery of a large oil field $45 \mathrm{~km}$ north of the Varanger Peninsula in the territorial waters of Norway.

The hydrocarbon types and their time of accumulation and localization indicate that these parameters are drasticcally different in the North and Norway seas from the adjacent East Barents Sea, Kara and Pechora basin areas (Figure 3). It is noteworthy that the gas-condensate accumulations on the southwestern and western fringes of the West-European Platform and Baltic Shield are associated with older sedimentary complexes, whereas the oil accumulations with younger ones. The picture is reversed in the eastern areas of the region.

The NordcapTrough mostly formed by the evolving Hercynides; its southern portion is a typical foredeep. It should be kept in mind that the Franz-Joseph Land uplift as well as the Severnaya Zemlya and Spitzbergen highs formed not so much due to these processes as to isostatic leveling of the continent's edge at the Arctic Ocean opening in Mesozoic. A large basement sag of the Svalbard Plate and the East Barents Sea depression formed due to the foredeep development on the autochthonous plate. On the other hand, this evolution was caused by the plate's variability and by the presence of the oceanic-type crust. That was the likely cause for the formation of such a large basement sag because usually foredeeps are narrow and long (Figure 4).

Often characteristic saddle-like structures emerge in the sediment cover warping process. They separate the cover into segments. One example is the Ludlow Saddle subdividing the East Barents Sea depression into the southern and northern segments. Another manifestation of the same principle is cross-highs (Vorkuta and Middle Pechora) separating the Urals Foredeep into segments (Figure 4). Their origins are most likely associated with the change of collision zone strike angle and, as a result, with the development of strike-slip deformations and warping structures. An important fact is that the aforementioned structures are overprinted by a system of rifts which intensify the basement sagging processes.

These processes facilitated the oil and gas migration from the subduction zone and their concentration at the boundaries of the structural complexes overprinted on the sediment formations of the pre-collision stage (Figures 3 and 4). It appears that these events led to the saturation by the "primary-migration" oil in the Varandey-Adzva structural zone and Khoreyver Depression of the thrusted and intensely-folded Ordovician-Silurian-Devonian sedimentary complexes. Besides, these processes facilitated the release and migration of the buried hydrocarbons 


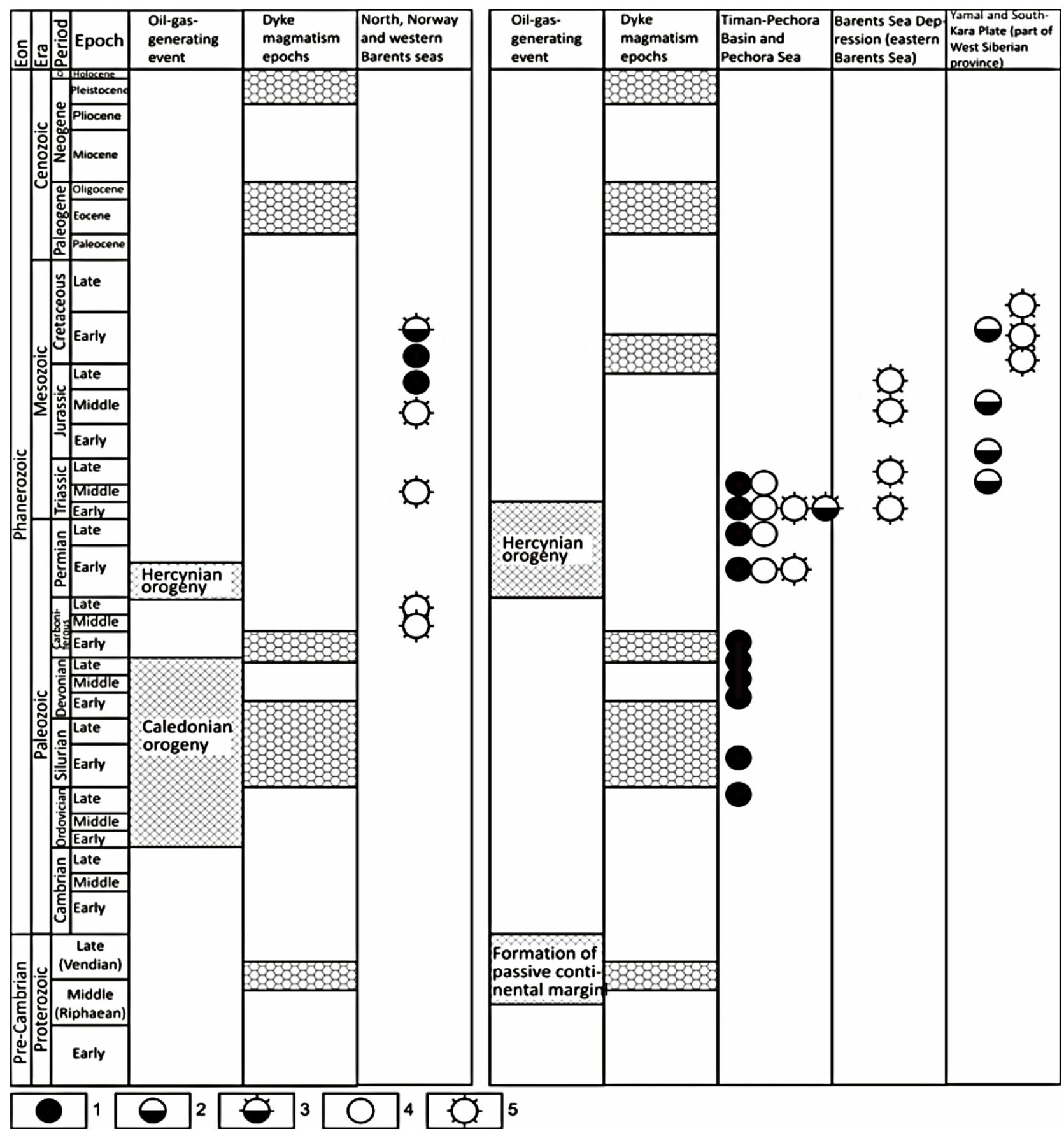

Figure 3. Oil-generating events and stratigraphic intervals of hydrocarbon type distribution in Barents-Kara and adjacent regions (modified from Shipilov, 1998, 2000). 1-5-hydrocarbon fields: 1-oil; 2—oil-gas; 3-oil-gas-condensate; 4-gas; 5-gas-condensate.

from the Riphaean time continental margin formations of the Izhma-Pechora Syneclise into the upper structural stages.

Figures 2 and $\mathbf{4}$ display the migration direction of oil generated during the Riphaean, Caledonian and Hercynian stages of tectonism. They also show the areas where the sediment cover formations can be saturated to a various degree (Figure 2). The crossing of axes of migration vectors must have resulted in maximum enrichment of sedimentary complexes in oil and gas accumulations, whereas their divergence, in the impoverishment in oil and gas fields.

A geostructural analysis of the subject region (Figures 2 and 4) indicates that the oil and gas potential in the sediment cover complexes on the South and North Kara Plates must be substantially greater than the offshore 


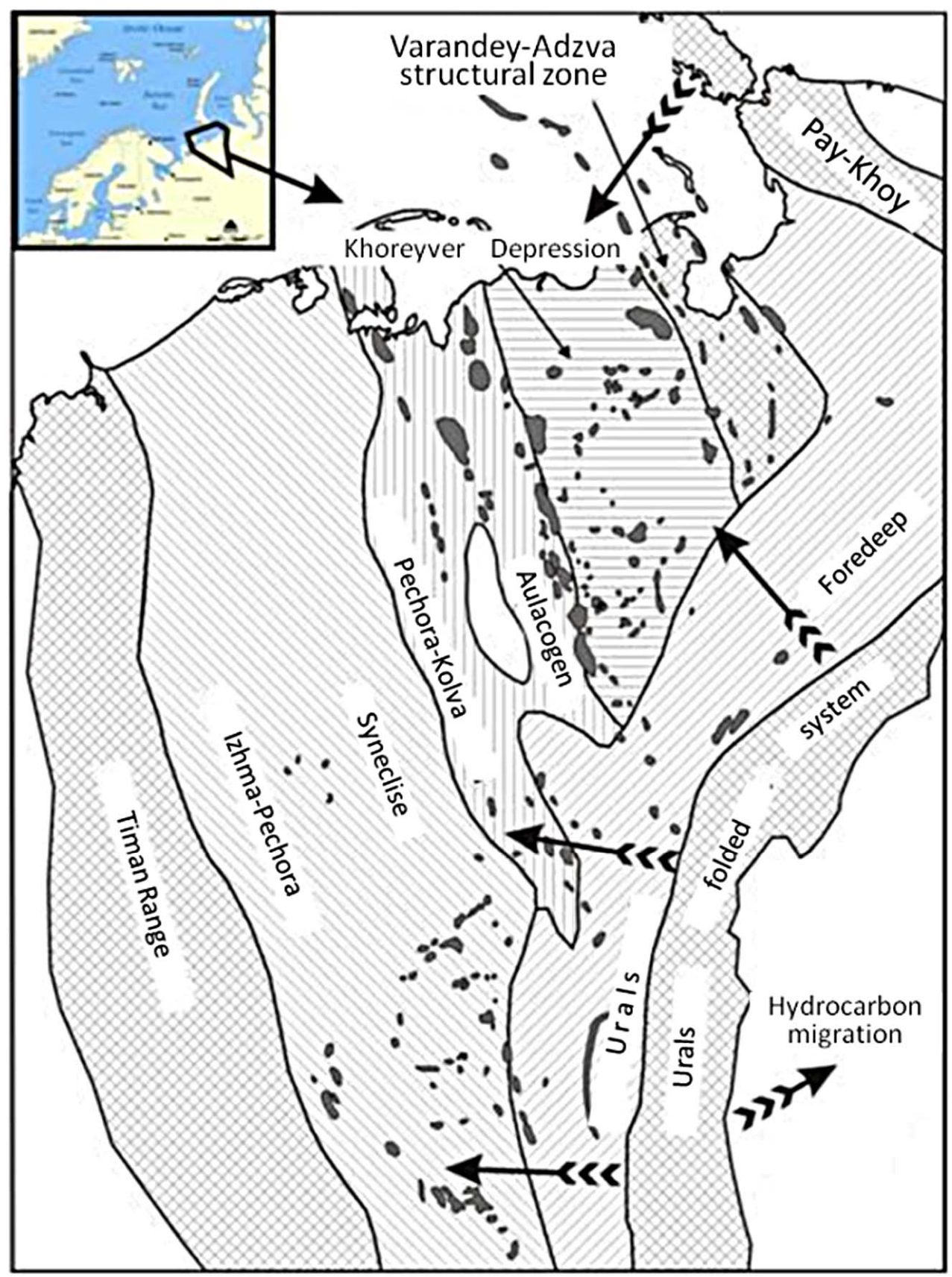

Figure 4. Schematic tectonic map of Timan-Pechora oil and gas province. (After Gromeka et al., 1994; and Kalantar et al., 1982).

Barents Sea. Equally rich is the northern and northeastern portions of the Timan-Pechora Plate and especially the Pechora-Kolvaaulacogen and the Khoreyver Depression. In most cases, the oil migration paths were bounded and concentrated by the narrow linear anticlines (megaswells). The oil was discharged along these structures and formed large accumulations.

Hydrocarbon concentration processes in the lithospheric plates' sediment cover suggest their time correlation with the hydrocarbon generating events. In our case, these processes are the continental margin deposition in Riphaean and two tectonic events, the Caledonian and Hercynian (Figure 3).

The source rocks for the primarily and secondarily migrated oil and gas within the Timan-Pechora, East Barents and Yamal-South Kara basins are structurallithological complexes not only contemporaneous with the tectonic events but also the younger ones (Figure 3). A noteworthy fact is that the hydrocarbon accumulations within the Timan-Pechora Basin are regularly distributed 
in space and time. Thus, the Ordovician, Silurian and Devonian sedimentary complexes include oil accumulations, whereas the Permo-Triassic contains oil, gas and gas-condensate accumulations.

There are no oil discoveries in the East Barents Sea Depression, and the gas-condensate accumulations are concentrated in the Upper Permian-Upper-Jurassic sequences. The Yamal-South Kara region comprises even younger localization age of the oil/gas and gas-condensate fields associated with the Middle Triassic-Lower Cretaceous rocks (Figure 3).

The spatial distribution of oil, gas and gas-condensate fields in the Timan-Pechora Basin shows that the latter are mostly associated with the Urals Foredeep and the areas of the Hercynian type syn-orogenicmagmatism. The most typical example is a large Vuktyl Field. It is most likely that the emergence of most gas-condensate accumulations in the region is associated with the syncollision magmatism and may be treated as secondary formations. The invasion of large magmatic masses into the hydrocarbon-rich source rocks resulted in the thermolysis and sublimation of oil and gas accumulations. That, in turn, led to their separation into predominantly gas-condensate and bitumen deposits.

As a result of these events, there was a regular hydrocarbon distribution in time: the oil and oil-gas accumulations are the oldest, whereas the gas and gas-condensate accumulations are younger (Figure 3). Oil accumulations in the Ordovician-Lower Devonian of the Khoreyver Depression and Varandey-Adzva folded zone are a reflection of the maximum manifestation of the folding and metamorphism. Perhaps that is why the oils there are severely degassed and have high density [6].

We believe that the Middle Devonian-Lower Carboniferous sediments in the Izhma-Pechora Syneclise include two complexes differing in the age of hydrocarbon formation. In this area and especially in its southwestern portion), the mixing of the Riphaean and Hercynian predominantly oil accumulations occurred with subsequent migration into the Devonian-Carboniferous rocks. The best example of the Riphaean stage oil and gas occurrences is the Yarega Field, which is found in the Devonian rocks.

The structural-lithological complexes controlling oil generation are limited in the East Barents Sea region to the Late Jurassic formations and in the South Kara and northern West Siberia Province, to the Late Permian formations (Figure 3). This represents a significant difference in time and localization of the oil-and gas-formation processes. Thus, these regions possibly belong to different oil and gas basins (areas, provinces).

The writers believe that the higher stress field parameters in the crustal block compared with the adjacent ones provides a longer migration time for the hydrocarbons and other fluids. A maximum manifestation of such processes could have resulted in the degassing of oil accumulations. Such processes are observed in the TimanPechora Basin where basement was squeezed between the Russian and West-Siberian plates.

Our study of the sediment cover of the Eurasian shelf's European portion suggests that the stress field in the eastern Barents Sea Plate over the post-Hercynian time was weaker than in the North-Kara and South-Kara regions. It is associated first of all with the geometric shape of the suture marking the lithospheric plates' collision zone. The oil and gas potential in the North- and SouthKara regions and in the Yamal Peninsula must be substantially higher than in the East Barents Sea Basin, and the age of accumulation must be younger (Figure 3).

The writers believe that the Upper Devonian-Lower Permian sediments served as the most likely oil source rocks for hydrocarbons (primary-migration). Klubov and Korago studied the oil potential in rocks of this age interval along the Novaya Zemlya west coast and discovered numerous shows of high-viscosity oil and solid bitumens [7]. The same was supported by Fedorovsky's findings for the Lower-Middle Devonian, Upper Frasnian-Famenian, Tournaisian, and Visean rocks in the Novaya Zemlya, Franz-Joseph Land and Spitzbergen archipelagos [8].

The degrading of hydrocarbon potential was associated first of all with the opening of the Arctic Ocean in Cenozoic. That led to the isostatic rebound and exposure on the surface of the continental shelf edge. The surface erosion destroyed fluid barriers in the oil-bearing Triassic-Jurassic sedimentary complexes and caused their degassing.

Thus, numerous indirect data testify to the omnipresence of oil in the Devonian-Early Permian sedimentary rocks in the East Barents Sea Depression. Their potential can turn out to be huge.

In the process of splitting of the formerly-united super continent Pangea and opening of the northern segment of the Atlantic and Arctic Oceans in Cenozoic (about 55 MMY ago), one more type of hydrocarbons formed in the region. It is represented by very peculiar and poorly studied gas with water compounds.

The gas-hydrate formation within the specified basins is still continuing. Dmitriyevsky et al. showed that it involves the entire offshore areas of the basins. The highest potential for the formation of economical deposits of gashydrates is associated with the Arctic Shelf and continental slope merger areas [9]. A large gas-hydrate accumulation was recently discovered southwest of the Spitzbergen Archipelago, near the Bear Island.

Recent data indicate that the stable gas-water compounds can also form in the internal areas of sedimentary sequences of shelf seas. An example is the gas-hydrate 
discovery in the well drilled on the Admiralty High west of the Novaya Zemlya Island [10].

Therefore, active tectonic zones of not only oceancontinent merger but also, under certain conditions, of the internal oceanic areas may have potential for the discovery of large gas-hydrate accumulations. Such areas may include the northwestern portion of the NorwayMezen rift system and the suboceanic-with-continental crust merger area within the Barents Sea Plate. All these zones display elevated heat flow, which enables water convection within sediment sequences [11].

The recent data [12] show that the formation of abiogenic hydrocarbon accumulations over the Arctic continental slope basins under certain conditions is accompanied by the organic hydrocarbon migration from the oil-and gas-saturated sequences of the continental shelf sediment cover. As an example, the Franz-Victoria Trough northwest of the Franz-Joseph Land is a rift formed in Late Permian-Early Triassic. The accumulation of primarily-migrated bitumens is observed in the lower portion of the seafloor deposits in its downthrown faultblocks. The collected samples contained methane, propane and other gases as well as bitumens (in the form of asphaltenes and maltines). It may be a result of hydrocarbon migration from the high-pressure zones (shelf sediment cover) into the continental slope. Most likely, these processes increase the oil and gas potential in the subject zone and may result in the formation of comercial accumulations.

There are quite a number of discovered and partially appraised large and unique oil and gas fields within the Barents-North Kara, Timan-Pechora and West Siberian provinces. In addition, at least three potentially hydrocarbon-rich, poorly studied areas are identified, which may substantially increase the entire region's oil and gas potential.

The first one is on the northern extremity of the Murmansk Oblast (in the Rybachy Peninsula, next to the regional administrative center). It is associated with the Riphaean sediments of the passive continental margin of that time. As indicated above, the Timan-Varanger lithospheric plate merger zone may have quite independent and, most likely, significant hydrocarbon potential.

The second prospective area is the Franz-Joseph Land Archipelago. There, rich Late Devonian-Early Permian oil and gas reservoirs in the Barents shelf sediment cover occur at a depth of 5 to $6 \mathrm{~km}$.

The third area with a high potential for discovery of large and possibly unique oil and gas fields is the North Kara Shelf. Based on our geodynamic analysis, this area may be compared in terms of its reserves with the South Kara and Yamal segments of the West Siberian oil and gas province.

The writers conducted more detailed studies within the first of the aforementioned areas. For this reason it is important to discuss its potential for oil and gas in some detail.

Two structural zones are identified within the area based on the combination of lithological data, intensity of deformations and extent of post depositional rock alterations. These zones are the Kildin and Rybachy.

The Kildin structural zone encompasses the Sredny Peninsula and Cape Motki (Rybachy Peninsula). Sediments of the Kildin and Volokov formations were deposited in Late Proterozoic under a pericratonic sag environment over northeastern edge of the East-European Platform (Figure 5). The Kildin series is of Late-Riphaean age of 1059 to 762 MMY obtained using the potassium-argon technique from glauconite in the sandstones of the lower portion series [13]. Besides, N. S. Mikhaylova determined the Late Riphaean age of the Kildin Series based on microfossil assemblage [14]. Samuelsson dated the Kildin Series age as Late Riphaean from the study of microfossils, acritarchs and cyanobacteria [15].

The alteration extent of the Kildin and Volokov sediments occurred during catagenesis. This is supported by the regeneration of quartz cement and by the presence of micro-stylolite structures. The Kildin and Volokov sediments have approximately an east-west strike and are almost horizontal. The dipangles do not exceed $10^{\circ}$ to $15^{\circ}$. Several nearly north-south faults were mapped. They are sinistral strike-slip faults with the offsets of no greater than a few hundred meters.

The age of the Rybachy Peninsula complexes can be considered either as Middle-Late Riphaean [16-20] or as Late Riphaean-Vendian [21-23].

The Rybachy Peninsula beds have a northwestern strike $\left(290^{\circ}-310^{\circ}\right)$ and northeastern $\operatorname{dip}\left(15^{\circ}-35^{\circ}\right)$. The rocks are slightly deformed into folds 400 - to $700-\mathrm{m}$ wide.

Noteworthy is the occurrences (described by T. P. Vronko, personal communication) of small overthrusts on the north shore of the Eina Bay in the south of the Rybachy Peninsula [21].

The rocks in the Rybachy Peninsula are cut by a system of sinistral strike-slip faults, with an offset of hundred meters to a few kilometers. Detailed geologic studies and geophysical surveys in the subject area, deciphering aerial and space images and the surface maps of the Barents Sea floor adjacent to the peninsula, enabled the writers to generate a schematic map of the fault-block structure for the Baltic Shield's northern extremity (Figure 6).

Magmatic shows are rare in the Rybachy Peninsula. The most common ones are northeasterly dolerite dykes in the northwestern part of the peninsula (Figure 5). They are usually 3- to 5-m thick and 100- to $150-\mathrm{km}$ long. Both the magmatism and rock deformations in the Rybachy Peninsula should be attributed to the Baikalian and 


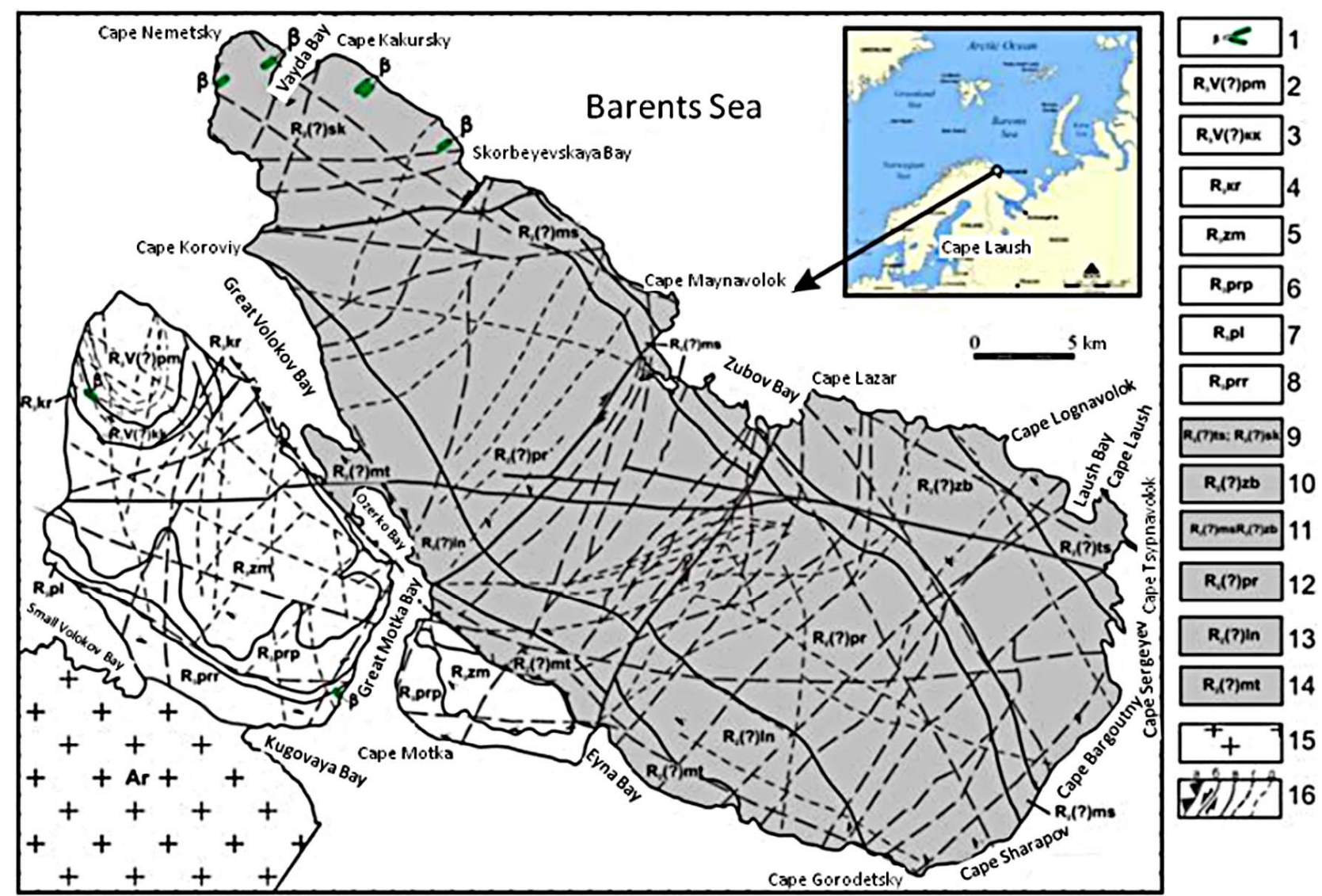

Figure 5. Formations and dolerite dykes of Rybachiy Peninsula: 1. Doleritedykes; 2-8. Upper Riphaean (Vendian): 2, 3. Volokovaya Series: 2. Puman Fm. (alternating yellowish-gray arkose psammites, silstones and dark pelites; 3 . Kuyakan Fm. (yellowish-gray polymictic conglo-breccias with phosphorite fragments, arkose gravelites and psammites with thin dark siltstone and pelite interbeds; 4-8. Kildin Series: 4. Karuyarva Fm. (alternating variegated arkose and oligomicticpsammites, siltstones and dolomites); 5. Zemlepakhtin Fm. (yellowish-gray arkose psammites with thin siltstone and pelite interbeds containing lenses of phosphoritic rocks); 6. Poropelon Fm. (alternating gray-green arkose psammites and dark siltstones); 7. Palvin Fm. (alternating variegated quartz, oligomictic and arkose psammites, siltstones, pelites and dolomites); 8. Pyaryayarve Fm. (alternating gray-green and quartz, oligomictic and arkose psammites, dark siltstones and pelites); 9-14. Middle Riphaean: 9-11. Bargoutnaya Series: 9. Tsipnavolok and Skarbeyev formations: alternating argillites and siltstones with carbonate rock lenses; 10. Zubov Fm. (alternating gray polymictic psammites, siltstones, pelites); 11. May Fm. (alternating gray quartz andpolymictic conglomerates with polymictic psammites); 12-14. Eynov Series: 12. Perevalnaya Fm. (gray polymictic psammites and gravelites with rare polymictic conglomerate, siltstone and pelite interbeds); 13. Lon Fm. (alternating gray polymictic conglomerates, gravelites, psammites with rare siltstone and pelite interbeds); 14. Motov Fm. (gray polymictic conglo-breccias with polymictic psammite interbeds and rare siltstone and pelite interbeds and lenses); 15 . unsubdivided Neo-Archaeantonalite-granodiorite complex; 16. faults: a-c, first-rank faults: a. thrusts and reverse faults-strike-slip faults, b. strike-slip faults, c. faults of unclear kinematics, d. second-rank faults; e. third rank faults.

Caledonian orogenies. This is supported also by paleomagnetic data [24].

Integrated geologo-geophysical data analysis of the northern Kola Peninsula (Rybachy Peninsula) enabled us to identify an area prospective for hydrocarbon exploration (Figure 7).

Our studies demonstrated a leading role of the tectonic processes in the formation of the region's present-day geologic scenario. They provided for a complex combination of the strike-slip and in part thrust tectonics in the superposition of the rock complexes on the Sredny and Rybachypeninsulas. The seismic data indicate that the total thickness of the Riphaean sediment cover in these areas reaches 3.5 to $4 \mathrm{~km}$. Its lower intervals include the rocks of Kildin complex, which display favorable geochemical properties for the hydrocarbon accumulation.

\section{Conclusions}

The main conclusions can be summarized as follows:

1) Geodynamic analysis identified areas on the Russia's western Arctic shelf prospective for oil and gas formation. It was established that the region's oil and gas potential formed as a result of four stages of the conti- 


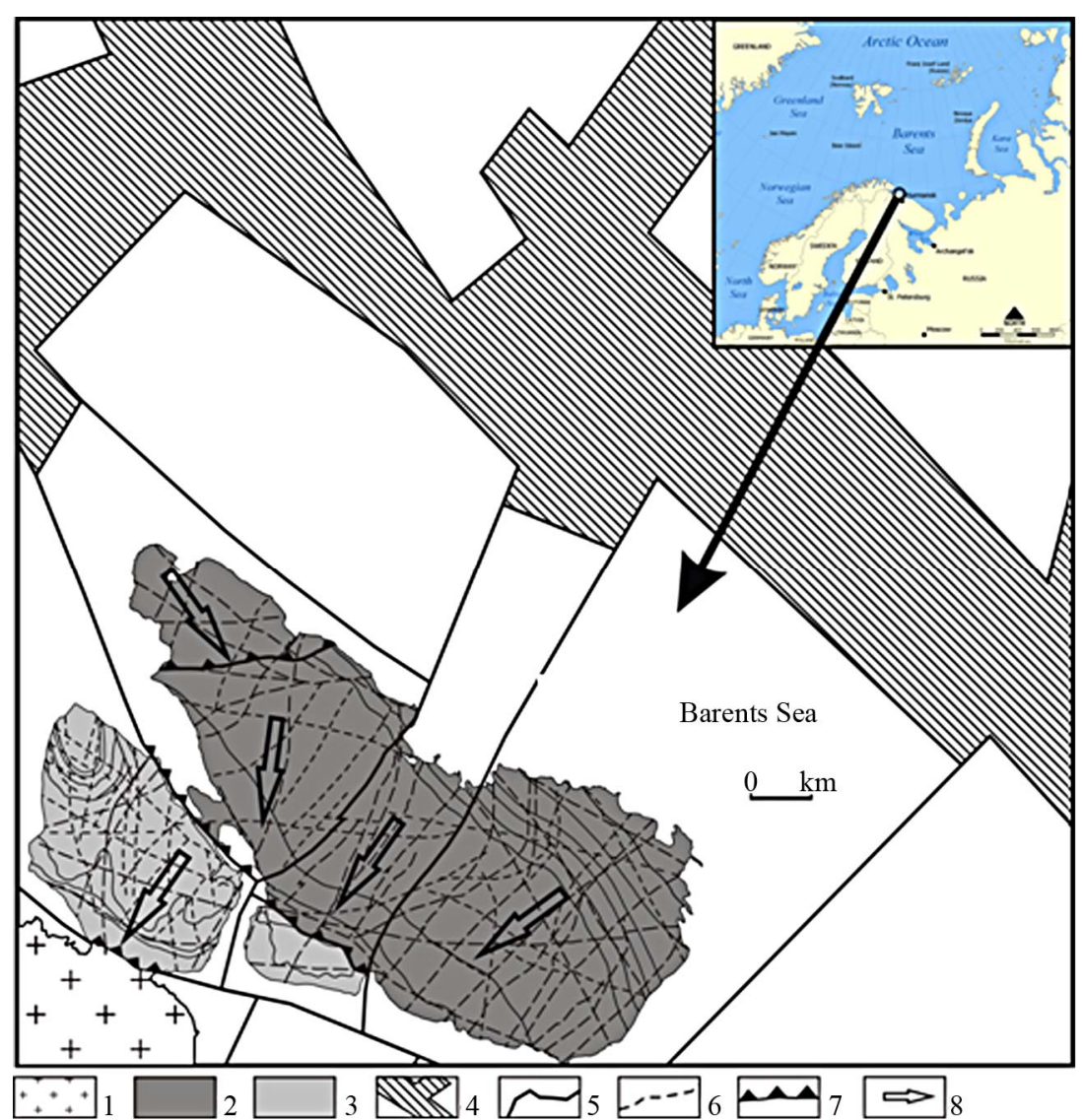

Figure 6. Kinematic schematic map of the fault-block structure in the nearshore zone of the Baltic Shield northeastern extremity. 1. unsubdivided Neo-Archaean tonalite-trondhjemite complex; 2. Middle Riphaean sediments; 3. Upper Riphaean and possibly Vendian sediments; 4. sag structures of the Baltic Shield basement in the Norway-Mezen rift zone; 5. fault-block boundaries; 6. faults; 7. reverse faults, reverse fault-thrusts and thrusts; 8. directions of crust-blocks offsets.

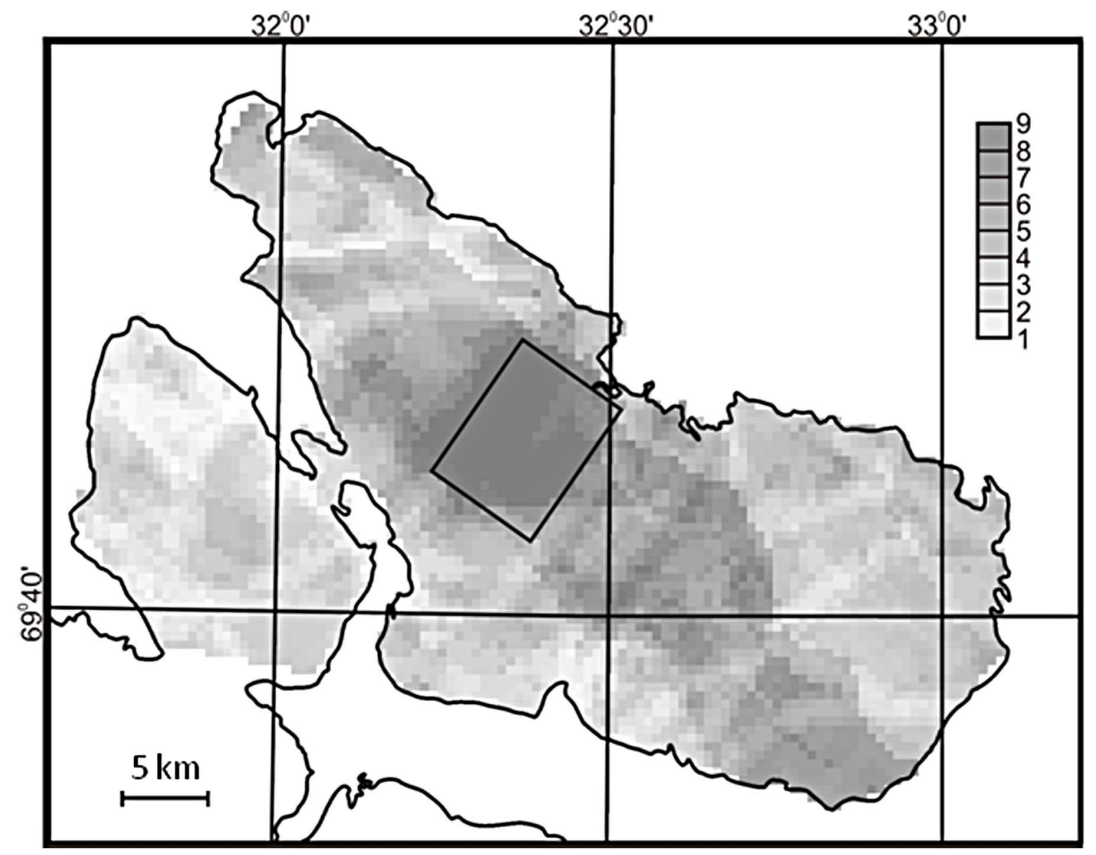

Figure 7. Calculation of the complex index with equilibrium weight function for the Sredniy and Rybachiy peninsulas (Kola Peninsula). The higher the complex index, the higher the area potential. 
nental lithosphere aggregation and transformation. Each of these changed the fringes and the internal areas of the subject region by the sequential aggregation of the continental crust and build-up of its sediment cover. They also resulted in a regular spatial and temporal distribution of large and unique hydrocarbon accumulations.

2) Along with the discovered and partially appraised large and unique oil and gas fields within the BarentsNorth Kara, Timan-Pechora and West Siberian provinces, at least three potentially hydrocarbon-rich (but insufficiently studied) areas were identified. The discovery of commercial accumulations there would substantially increase the oil and gas potential of the entire region.

3) The study of the integrated set of geologo-geophysical parameters suggested the potential hydrocarbon prospects within the Rybachy Peninsula (Kola Peninsula).

\section{REFERENCES}

[1] V. V. Lyubtsov, I. A. Petersilye and A. A. Predovsky, "Hydrocarbons and Organic Carbon in the Upper Riphaean Sediments of the Noerhwestern Kola Peninsual," Proceedings of the USSR Academy of Sciences, Vol. 214, No. 4, 1979, pp. 912-916.

[2] A. P. Simonov, et al., "Riphaean Oil of the Rybachy Peninsula: A Myth or a Key to the Radically New Direction in Oil Exploration on the Barents Sea Shelf," Herald MGTU, Vol. 1, No. 2, 1998, pp. 121-140.

[3] O. G. Sorokhtin, "Life of the Earth," Scientific Center, Regular and Chaotic Dynamics, Moscow, 2007, 452 p.

[4] A. N. Dmitriyevsky, et al., "Hydrothermal Mechanism of Hydrocarbon Formation in Mid-Oceanic Ridges (on Example of the Barents and Norway Seas)," Geology Oil and Gas, Vol. 8, 1997, pp. 10-24.

[5] I. S. Gramberg, et al, "Arctic Oil-Bearing Superbas," In: Yu. N. Kulakov, Ed., Oil and Gas Bearing of World Ocean, Sevmor-Geologiya, Leningrad, 1984, pp. 5-24.

[6] V. I. Gromeka, et al., "Location Patterns and Exploration Prospects for Oil and Gas Fields in the Timan-Pechora Province," Geology Oil and Gas, Vol. 6, 1994, pp. 42-47.

[7] B. A. Klubov and E. A. Korago, "On the Nature of Liquid Bitumens in the Northern Novaya Zemlya," Proceedings of the USSR Academy of Sciences, Vol. 315, No. 4, 1990, pp. 925-928.

[8] Yu. F. Fedorovsky, "Oil and Gas Potential of the Upper-Middle Paleozoic Carbonate Sediments on the Russian Shelf of the Barents Sea," Ph.D. Dissertation, Moscow, 2007.

[9] T.V. Dmitriyevskaya, et al., "Neotectonic Motion Amplitude Effect on the Distribution of Oil and Gas Fields in the Section of the Timan-Pechora Basin," Geology Oil and Gas, Vol. 10, 1999, pp. 8-12.

[10] V. V. Semenovich, and V. V. Nazaruk, "Oil and gas occurrences in the southeastern Barents Sea Shelf," Geology
Oil and Gas, Vol. 6, 1992, pp. 26-34.

[11] V. G. Levashkevich, "Distribution Patterns of the Geothermal Field in the Fringes of the East-European Platform (Barents Sea and Belorussian-Baltic Regions)," Ph.D. Dissertation, Moscow University, Moscow, 2005.

[12] E. P. Shkatov, et al., "On the Issue of Oil and Gas Potential in the Northern Areas of the Barents-Kara Shelf (Franz-Victoria Trough)," Geology Oil and Gas, Vol. 4, 2001, pp. 12-16.

[13] Yu. R. Bekker, V. Z. Negrutsa and N. I. Polevaya, “Ages of Glauconite Horizons and Hyperborean Upper Boundary in the Eastern Baltic Shield," Proceedings of the USSR Academy of Sciences, Vol. 193, No. 5, 1970, pp. 1123-1126.

[14] V. V. Lyubtsov, N. S. Mikhaylova and A. A. Predovsky, "Late Cambrian Lithostratigraphy and Microfossils of the Kola Peninsula, Apatity," Kola Scientific Center of Russian Academy of Sciences, 1989.

[15] J. Samuelsson, "Biostratigraphy of Kildin Island and Sredniy Peninsula: Preliminary Results," Norwegian-Russian Collaboration Programme (North Area), 1st International Barents Symposium (Abstracts), Kirkenes, 1993.

[16] B. M. Keller and B. S. Sokolov, "Late Pre-Cambrian of the Northern Murmansk Oblast," Proceedings of the USSR Academy of Sciences, Vol. 133, No. 5, 1960, pp. 1154-1157.

[17] B. M. Keller, A. V. Kopeliovich and B. S. Sokolov, "Rybachy, and Sredny Peninsulas and Kildin Island," Stratigraphy of the USSR, Upper Pre-Cambrian, 1963, pp. 103-113.

[18] N. G. Konopleva, "Upper-Proterozoic Rhythmic Sequence of the Rybachy Peninsula," Proceedings of the USSR Academy of Sciences, Vol. 219, No. 1, 1974, pp. 175-178.

[19] N. M. Chumakov, "Pre-Cambrian Tillites and Tilloids (Pre-Cambrian Glaciations)," Nauka, Moscow, 1978.

[20] Yu. R. Bekker, "Pre-Cambrian Molasses," Nedra, Leningrad, 1986.

[21] E. M. Lyutkevich and L. Ya. Kharotonov, "Pre-Cambrian sediments of the Rybachy and Sredniy Peninsulas and Kildin Island," Geology of the USSR, Moscow, 1958, pp. 361-370.

[22] V. Z. Negrutsa, "Stratigraphy of the Hyperborean Sediments, Rybachy and Sredniy Peninsulas and KildinIsland," Pre-Cambrin Geology on the Baltic Shield and in the Russian Platform Sediment Cover, Nedra, Leningrad, 1971, pp. 153-186.

[23] E. I. Sergeyeva, "Major Features of the Late Pre-Cambrian Composite Section in the Kola Peninsula," Karelo-Kola Region Geology, Thematic Assemblage of Scientific Procedures, Moscow, 1973, pp. 3-15.

[24] T. Torsvik, D. Roberts and A. Siedlecka, "Paleomagnetic Data from Sedimentary Rocks and Dolerite Dykes, Kildin Island, Rybachi, Sredni, and Varanger Peninsulas, NW Russia and NE Norway," Norwegian-Russian Collaboration Programme (North Area), 1st International Barents Symposium, Kirkenes, 1993. 